\title{
焼成した造粒凝灰岩風化土のリン酸吸着特性
}

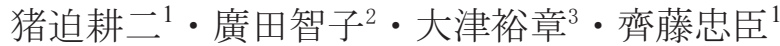

\section{Phosphorus Adsorption Property of Baked Granulated Substance of Weathered Soil of Tuff}

\author{
Koji Inosako ${ }^{1}$, Tomoko Hirota ${ }^{2}$, Hiroaki Otsu ${ }^{3}$, and Tadaomi Saito ${ }^{1}$
}

\begin{abstract}
Since the structure of the weathered soil of tuff, which is generated as excavated soil by farm road improvement projects in Mt. Daisen area in Tottori, is easily destroyed, it cannot be reused and is dumped as industrial waste. The soil also easily becomes muddy and pollutes rivers. In this study, we made a baked granulated substance of the soil (BGD) and evaluated its adsorptive capacity for dissolved phosphorus and clarified the following points. 1) The phosphate absorption coefficient of BGD was changed by sintering treatment temperature and became maximum: $6.22 \mathrm{gP}_{2} \mathrm{O}_{5} / \mathrm{kg}$ at $500^{\circ} \mathrm{C}$. 2) We found that active aluminum played an important role in the phosphorus adsorption of BGD. 3) The concentration of the dissolved phosphorus in the solution was decreased by immersion treatment of BGD. However, the effect failed to continue in repeated uses. 4) BGD can be reused in farmland after adsorption treatment because the amount of available phosphorus in BGD reached 70 to $80 \%$ of the amount of the absorbed phosphorus.
\end{abstract}

Keywords: Absorbent; Temperature of heating; Phosphate absorption coefficient; Active aluminum

\section{1 はじめに}

鳥取県西部にある江府町では, 農道整備事業によって凝 灰岩風化土が掘削土として多量に発生している.この土は 外観が真砂土に類似していることから, 地元では「大山マ サ」と通称されている. 大山マサは, 練り返すことにより土 㙋構造が破壊されやすくなるため, これまでいかなる用途 にも利用できず産業廃棄物として残土処理地に捨てられ てきた. 土壊構造が破壊された大山マサは容易に流動化 するため, 降雨発生時には濁水となって処理地近傍の河 川等に流入し, 著しい水質污濁を起こしている. そのため, 残土処理量の削減を目的とした有効利用が望まれるように なった。これまで大山マサの土質特性や物理特性につい て研究されてきたが(新ら，2002), 有効な利用方法は未 だ確立されていない。

土壌にはリン酸吸着機能があり,これを利用することで 溶存少ン酸の回収が可能となる. 若月ら(1989)は, 異なる 土性を充填した多段式土壌浄化装置を開発し, 生活排水 中のリン酸の回収に有効であることを示した. また, 古庄ら (2008)は土壌力ラムによる污染水の浄化実験を行い, リン 酸に対する土壌の浄化能力の高さを確認している.

土壌のリン酸吸着能を表す指標として, リン酸吸収係数 が用いられる. 土壤のリン酸吸収係数は加熱することで増

\footnotetext{
鳥取大学農学部教授, Professor, Faculty of Agriculture, Tottori University, 4-101, Koyama-cho Minami, Tottori 680-0945, Japan (Corresponding Author) E-mail:inosako@muses.tottori-u.ac.jp

株式会社オリエンタルコンサルタンツ, Engineer, Oriental Consultants Co., Ltd., 3-12-1, Honmachi, Sibuya-ku, Tokyo 141-0071, Japan

（株）ジーエス環境科学研究所, Engineer, GS Environmental Science Laboratory Co., Ltd. 5, Ichinodancho, Shinden, Kisshoin, Minami-ku, Kyoto-shi, Kyoto 601-8397, Japan

${ }^{4}$ 鳥取大学農学部講師, Junior Associate Professor, Faculty of Agriculture, Tottori University, 4-101, Koyama-cho Minami, Tottori 680-0945, Japan
}

加することが報告されている(柳田と江, 1994). 近年, この 効果を利用して, 溶存少ンを除去する水質浄化材として加 熱土畩を利用する土壤吸着法に注目が集まっている(三 谷ら, 2003 ; 江ら, 2004, 2005a, 2005b).これは, 土畩の $\mathrm{Fe} \cdot \mathrm{Al}$ 酸化物鉱物やアロフェン表面のFeやAlイオンに配 位 (共有結合)した $\mathrm{OH}^{-}$が，リン酸イオンと交換して吸着す る配位子交換反応を利用したものである.

良く知られているように土壌を成形した上で高温焼成す ると容易にはその形状が崩壊しない. 筆者らは予備実験 によって大山マサを成形し高温焼成することで水に対する 流動性が消失されることを見出した。

本研究では, 焼成によって水に対する流動性を消失さ せた造粒大山マサのリン酸吸着材としての利用について の可否を検討するために, リン酸吸着特性について検討 した.

\section{2 実験材料と方法}

\section{1 供試土壌と造粒大山マサの作成}

実験には，鳥取県西部の江府町で採土された大山マサを 風乾して使用した. 表1に大山マサの基礎的諸量を示した. 土粒子密度, 粒径組成はJIS A1202 (地盤工学会, 2008a) およびJIS A1204(地盤工学会, 2008b)に従って定量した. また, 構成元素については蛍光X線分析法のファンダメン タルパラメータ法 (加藤ら, 1998)より推定した.

大山マサの成形は次の手順で行った. 風乾させた大山 マサを $2 \mathrm{~mm}$ ふるいにかけ, ボールミルで24時間粉砕した. 粉砕の理由は均等な形状で造粒するためである.この粉 砕した土㙵に適量の水を加えて良く練り合わせ粒径約 $10 \mathrm{~mm}$ 程度の球状に成形した。これを $110^{\circ} \mathrm{C} て ゙ 1$ 時間乾燥さ

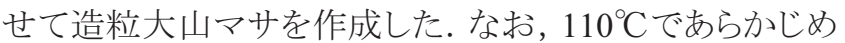


乾燥させる理由は, 高温焼成によるひび割れの発生を防 止するためである.

表 1 : 大山マサの基礎的諸量と構成元素

\begin{tabular}{c|c|c}
\hline \multicolumn{2}{c|}{ 土粒子密度 $\left(\mathrm{g} / \mathrm{cm}^{3}\right)$} & 2.723 \\
\hline & 碟分 & 13.3 \\
$\begin{array}{c}\text { 粒径組成 } \\
(\%)\end{array}$ & 砂分 & 54.3 \\
& シル下分 & 10.4 \\
& 粘土分 & 22 \\
\hline \multirow{2}{*}{$\begin{array}{c}\text { 構成元素 } \\
(\%)\end{array}$} & $\mathrm{SiO}_{2}$ & 57.8 \\
& $\mathrm{Al}_{2} \mathrm{O}_{3} \mathrm{O}_{3}$ & 36.8 \\
& $\mathrm{CaO}$ & 2.07 \\
& その他 & 1.39 \\
\hline
\end{tabular}

\section{2 焼成処理}

造粒した大山マサをマッフル炉で焼成し, 焼成造粒大山 マサ (Baked Granulated Daisen-masa, 以後BGD之称 す)を作成した (写真 1). 前述したように, 大山マサは焼 成することで水に対する流動性を失う. 写真2 2 焼成前と 焼成後の造粒大山マサをガラス瓶に浸漬したものである. 焼成前のものは浸漬後直ちに崩壊したが, 焼成後は形状 を保ったままであった。

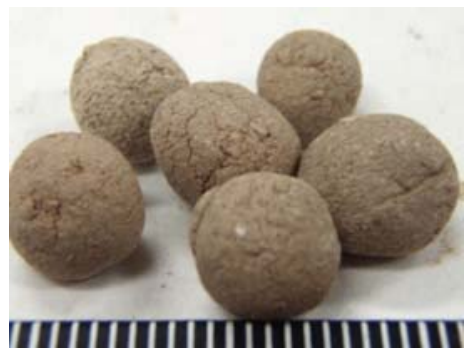

写真 1 : 焼成造粒大山マサ

リン酸吸着能を最大化させる焼成温度を明らかにするた めに, $300,400,500,600,700,800^{\circ} \mathrm{C}$ の 6 の温度設定 で焼成した. なお, 焼成時間は予備実験の結果から1時間 とした.

\section{3 リン酸吸着能の測定}

BGDのリン酸吸着能の評価にはリン酸吸収係数を用いた。 リン酸吸収係数は, 土壤がリン酸を吸着, 保持する能力を 表す指標であり, 乾土 $100 \mathrm{~g}$ 当たりの $\mathrm{P}_{2} \mathrm{O}_{5}$ 量 $(\mathrm{mg})$ で表示さ れる.わが国におけるデータの蓄積量が多いため, BGD のそれを他の土袞の測定例と比較することによってBGD のリン酸吸着に関する性能評価が可能となる. リン酸吸収 係数はリン酸アンモニウム液法 (南條, 1997a) で定量し, その際の試料/溶液比は1/40とした。

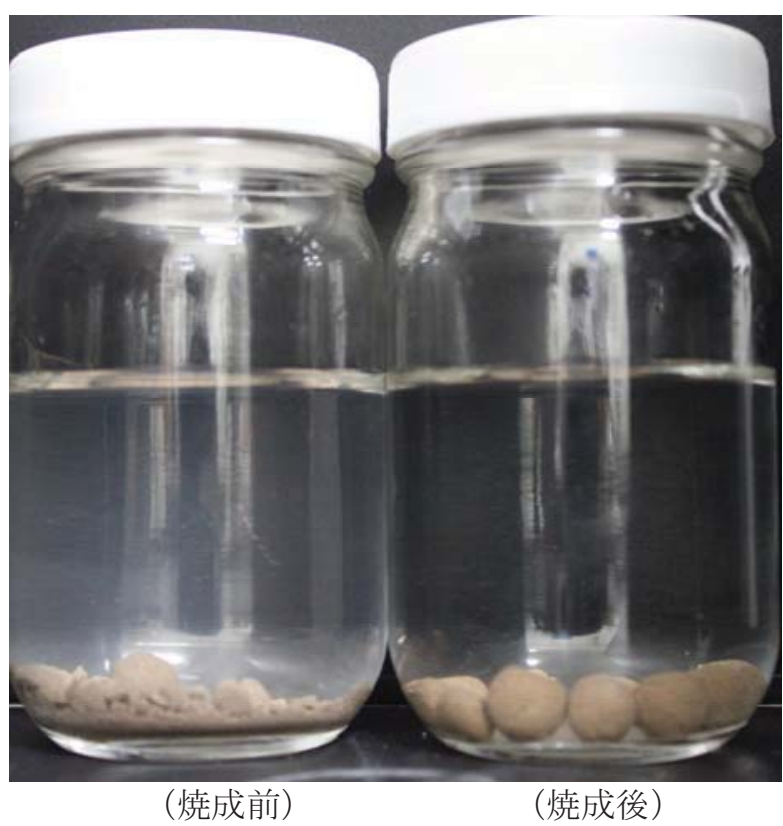

写真 2 : 焼成前後での大山マサの水に対する流動性

リン酸を吸着する土壌成分は活性アルミニウム, 活性鉄 といわれている(南條，1989）. 活性アルミニウムと活性鉄 の主要成分は酸性シュウ酸塩溶解法(伊藤, 1997) によっ て得られる酸性シュウ酸塩可溶性アルミニウム $(\mathrm{Alo}) \cdot$ 鉄 (Feo)である. そこで, 焼成による造粒大山マサのリン酸吸 着能の変化の要因を明らかにするために, 最も少酸吸収 係数が最も高くなる時の温度で焼成した際のAloおよび Feoと未焼成段階でのそれらを測定した。 なお, Aloおよび Feoの測定は伊藤(1997)に従ったが, アルミニウムと鉄の 定量にはICP吸光光度法を用いた. これらの分析は三連 で実施した。

\section{4 浸漬実験}

リン酸吸着材としての性能評価を行うためにリン酸溶液で の浸漬実験を行った. $20 \mathrm{ppm}$ のリン酸溶液 $100 \mathrm{~mL}$ をれれ ガラス瓶にBGD $5 \mathrm{~g}$ を入れて密閉した. これを $25{ }^{\circ} \mathrm{Cのイン}$ キュベータ内に静置し， 1，3，5，7，15日目の溶液中のリン 酸濃度を測定した. リン酸濃度の測定はモリブデン青法 (川村, 1995)によった. また, 実験終了時にBGD中の可 給態リン酸量をブレイ第二法(南條, 1997b)で測定した.

また, 15 日静置した後にBGDを取り出し, $110^{\circ} \mathrm{C}$ で1時間 乾燥させた後に, 再度 $20 \mathrm{ppm}$ のリン酸溶液に浸漬し, 上述 の方法で静置実験を行った. これを1サイクルとし, 5回繰り 返して, BGDの繰り返し使用による吸着性能の変化を調 ベた.

なお,これらの実験にはリン酸吸収係数が最も高くなる 温度で焼成したBGDを使用した。

\section{3 結果と考察}

\section{1 土壌の焼成処理によるリン酸吸着能の変化}

Dyal and Hendricks (1950)によって提案されたエチレング リコール保持法で比表面積を測定したところ, 粉砕によっ 
て約 $1700 \mathrm{~m}^{2} / \mathrm{g}$ から $1900 \mathrm{~m}^{2} / \mathrm{g}$ まて増加した。 しかし, 焼成温 度による増加は認められなかった。

図 1に示したように, 焼成温度の上昇に伴ってBGDのリ ン酸吸収係数は増加し, 焼成温度 $500^{\circ} \mathrm{C}$ で最大となった。 このときのリン酸吸収係数 $6.22 \mathrm{gP}_{2} \mathrm{O}_{5} / \mathrm{kg}$ は焼成前の值 $\left(5.23 \mathrm{gP}_{2} \mathrm{O}_{5} / \mathrm{kg}\right)$ の 1.2 倍に相当する.これは温度の上昇に よって土壌鉱物の破壊が進み, 非晶質鉱物が生成された ためと思われる. $500^{\circ} \mathrm{C}$ 以上ではリン酸吸収係数は減少し, $800^{\circ} \mathrm{C}$ では焼成前の $70 \%$ 程度となった。これは, ある温度 以上になると非晶質鉱物が準晶質や結晶質鉱物 (結晶質 酸化鉄・アルミニウム) に転換されるため, 活性及び遊離 鉄・アルミニウムが減少したためと思われる. 江ら(2004)は 他の土袞を用いた実験を行い, 同様の現象を報告してい る.

焼成によってリン酸吸収係数は増加しているが，一般に リン酸吸収係数が高いとされる火山灰土では 43.4

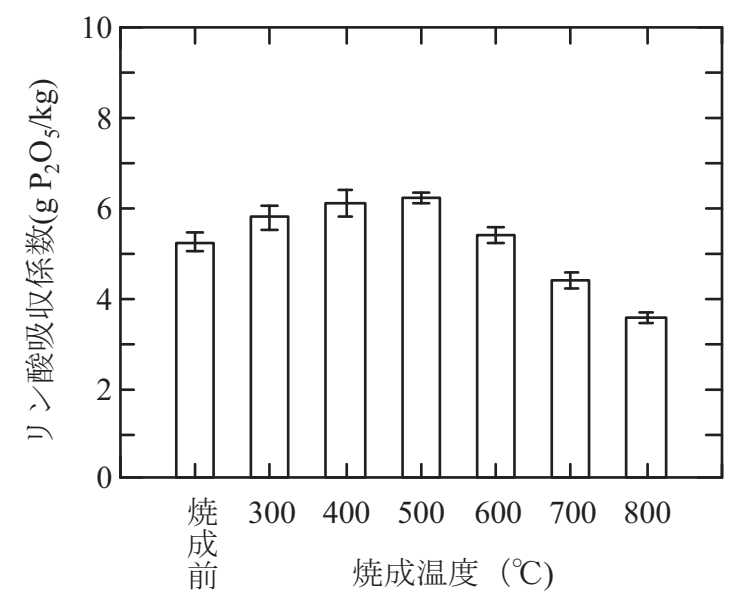

図 $1:$ 焼成温度によるリン酸吸収係数の変化
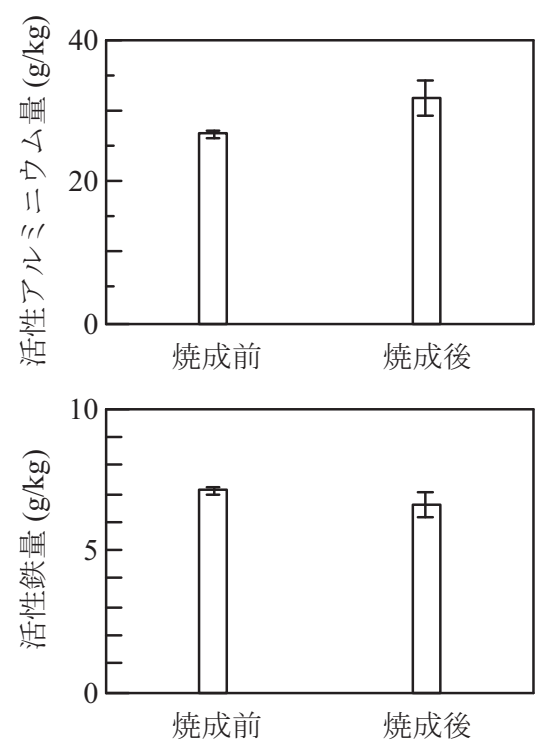

図 2 : 活性アルミニウム量と活性鉄量 の焼成前後での変化
$\mathrm{gP}_{2} \mathrm{O}_{5} / \mathrm{kg}$ (三谷ら, 2000), $36.2 \mathrm{gP}_{2} \mathrm{O}_{5} / \mathrm{kg}, 25.9 \mathrm{gP}_{2} \mathrm{O}_{5} / \mathrm{kg}$ (と もに柳田と江, 1994) との報告があり, これらに比べて著し く低く, 大山マサのリン酸能は絶対值としては小さいと考え られる。

リン酸吸収係数が最も高かった焼成温度 $500^{\circ} \mathrm{C}$ における 活性アルミニウムと活性鉄をみると，それぞれ $31.7 \mathrm{~g} / \mathrm{kg}$, $6.6 \mathrm{~g} / \mathrm{kg}$ であった。未焼成段階ではそれぞれ $26.7 \mathrm{~g} / \mathrm{kg}$ と $7.1 \mathrm{~g} / \mathrm{kg}$ であり, 焼成によって活性アルミニウム量が 1.2 倍に 増大していることがわかる(図 2)。これは大山マサを加熱 することにより，アロフェン骨格構造を成すAl-O-Si結合を 切断し, リン酸吸着部分である反応性に富んだ非晶質ア ルミニウムが, ヒドロキシル基(-OH)を生成したためと考えら れる(江ら, 2004). 焼成による活性鉄量の増加は認められ ず, BGDのリン酸吸着係数の増加は活性アルミニウムが 影響しているといえる.

なお, 以後のリン酸吸着能の性能評価実験には, $500^{\circ} \mathrm{C}$ で焼成したBGDを使用した。

\section{2 リン酸吸着材としての性能評価}

\subsubsection{5日間静置実験でのリン酸溶液の濃度変化}

図 3 に静置実験による溶液中のリン酸濃度ならびにpHの 変化を示した。

溶液中のリン酸濃度は指数関数的に減少し, 15 日目に は5.2ppmに達し，74\%のリン酸を吸着した. $\mathrm{pH}$ の変化をみ ると, 実験開始時はpH5とやや酸性側にあるが, リン酸吸 着とともに上昇し15日間でpH7に達した。これは, 次式に 示すように, GBDにおけるリン酸吸着による $\mathrm{OH}^{-} の$ 放出が 生じたためと思われる(南條，1989).

$$
\mathrm{Al}-\mathrm{OH}+\mathrm{H}_{2} \mathrm{PO}_{4}{ }^{-}=\mathrm{Al}-\mathrm{H}_{2} \mathrm{PO}_{4}+\mathrm{OH}^{-}
$$
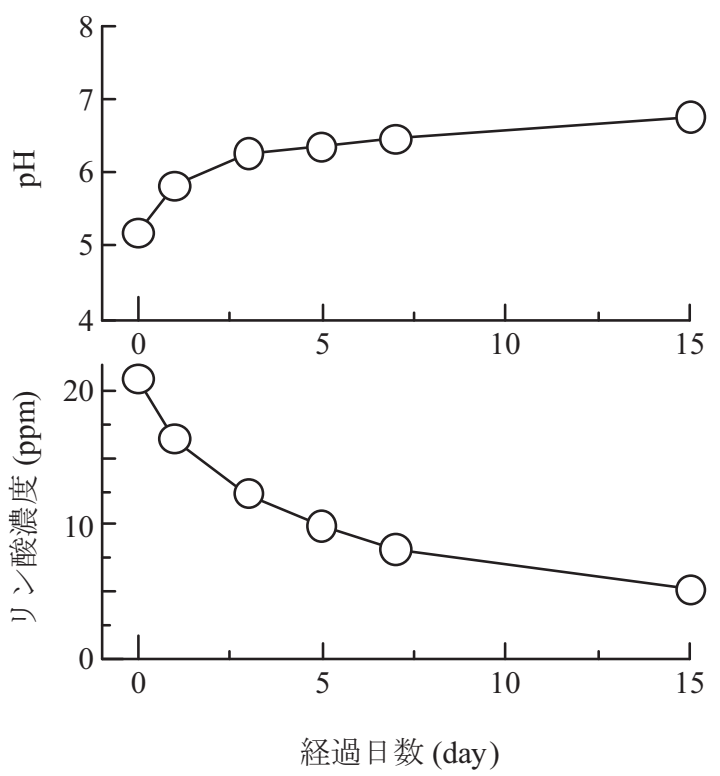

図 3:15日間浸漬実験における溶液中のリン酸濃 度と $\mathrm{pH}$ の変化 


\subsection{2 繰り返し使用時のリン酸吸着効果}

図4にBGDを繰り返し使用した場合のリン酸濃度の 変化を示した. 回数を重衫るたびにBGDへの吸着量が 減少し, 溶液中のリン酸濃度低下も5回目では1回目の 50 \%程度に留まった。

$\mathrm{pH}$ は繰り返し実験を行うことで明瞭な差はなく, $\mathrm{pH}$ 5から中性に向から方に上昇していった. これは少ン酸吸着 が, 大山マサが保持するAlと配位結合することで起こって いると考えられる. 従って吸着の際にAlの保持している反 応に富む $\mathrm{OH}^{-}$が水溶液中に放出され, その後水溶液中の $\mathrm{H}^{+}$と反応したと考えられる.

単なる乾燥による繰り返し使用ではリン酸吸着に反応可 能な部分が消失していくのみであり, 機能回復は期待でき ない. 再焼成あるいは酸による洗浄等を検討する必要が ある。

\subsection{3 使用済み吸着材の再利用}

リン肥料の原料であるリン鉱石は枯渴が予想されている貴 重な資源である(黒田ら, 2005).したがって, 土壌に吸着 されたリン酸は肥料としての再利用を検討しなければなら ない(新井と杉原, 1989). 水質浄化として利用された後の BGDを少酸肥料として農地に還元できれば, 大山マサの 利用法として極めて望ましい. そこで, BGDに吸着されたり ン酸の何\%が肥料として再利用可能かを検討した. 再利 用の可能性については, 吸着したリン酸量に対する可給

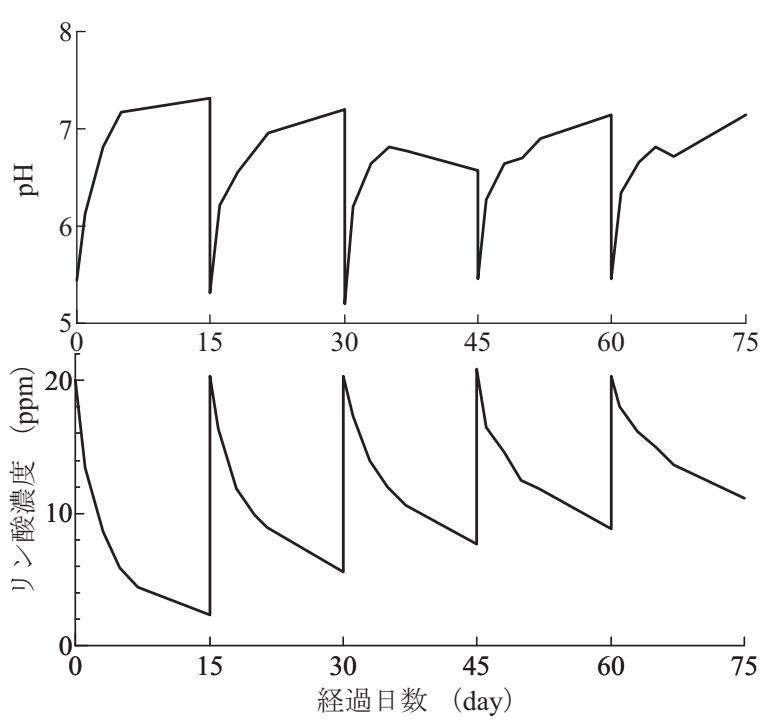

図 4 : 繰り返し使用によるリン酸濃度と $\mathrm{pH}$ の変化

表 2 : 繰り返し使用における吸着リン酸量と可給態 リン酸量の変化

\begin{tabular}{cccc}
\hline $\begin{array}{c}\text { 繰り返し回数 } \\
\text { 1 }\end{array}$ & $\begin{array}{c}\text { リン酸吸着量 } \\
\mathrm{A}(\mu \mathrm{g})\end{array}$ & $\begin{array}{c}\text { 可給態リン酸量 } \\
\mathrm{B}(\mu \mathrm{g})\end{array}$ & $\mathrm{B} / \mathrm{A}(\%)$ \\
\hline 2 & 326 & 258 & 79.1 \\
3 & 583 & 470 & 80.6 \\
4 & 798 & 637 & 79.8 \\
5 & 993 & 807 & 81.3 \\
\hline
\end{tabular}

態リン酸量の比で表した(表2).

可給態リン酸量は吸着したリン酸量の $70 〜 80 \%$ に達し, ほぼ一定であった. 使用後のBGDを土壌に散布した場合, 吸着したリン酸量に対して70〜80\%は作物に吸収可能な リン酸として土壌に供給できるといえる.このことが作物栽 培において, どの程度の価值を有するかは今後の実験で 明らかにする必要がある.

\section{4 おわりに}

本研究では有効な処理方法のない大山マサの焼成造粒 物を作成し，リン酸吸着材としての利用可能性を検討 するためにリン酸吸着特性について実験を行った。そ の結果以下のことが明らかとなった。

1) 造粒大山マサのリン酸吸収係数は $5.23 \mathrm{~g}_{2} \mathrm{O}_{5} / \mathrm{kg}$ と 他の土壌に比べて小さいが, 焼成することで $20 \%$ 程 度大きくなり， $6.22 \mathrm{~g} \mathrm{P}_{2} \mathrm{O}_{5} / \mathrm{kg}$ となった。

2) リン酸吸収係数は焼成温度 $500^{\circ} \mathrm{C}$ で最大となる.

3）焼成造粒大山マサのリン酸吸着は活性アルミニウ ムが主要因として機能する.

4) 焼成大山マサを高濃度溶存リン酸溶液に浸漬する と, 指数関数的に溶液中のリン酸濃度が低下した。

5）再利用時にはリン吸着量は低下し，5回で1回目の $50 \%$ 程度の濃度低下に留まった。

6) 溶存リン酸吸着後の焼成造粒大山マサでは, 可給態 リン酸量は吸着したリン酸量の $70 \sim 80 \%$ に達しており, 土袞へのリン供給源として期待できる。

以上の結果から, 焼成造粒大山マサは溶存少ン酸の吸 着材として使用できるものの, 現状では優れた素材である とは言い難い. しかし, 焼成処理によって水に対寸る流動 性を消失させ少ン酸吸着能を高められたといら事実は, 利 用方法がなく産業廃棄物として処分するより他に方法のな かった大山マサ残土に使途を与えるものであり, 有効利用 の可能性を示唆するものである. その点において本研究 の成果は意義があるといえる. 大山クロボクや火山灰質粘 性土などリン酸吸収係数が高いと思われる地場土壤を添 加することでリン酸吸着能を高めることも可能と思われるた め, 今後,さらに詳細な実験を継続していきたい.

\section{引用文献}

[1] 新任修・坂口雅範・藤村尚 (2002) : 大山火山粉屑岩の 工学的性質について, 地盤と建設, 20, pp.109-116.

[2] 新井重光・杉原進 (1987)：土壤中における窒素・リン の挙動，水質污濁研究，10(7)，pp.402-406.

[3] Dyal, R. S., and Hendricks S. B. (1950): Total surface of clays in polar liquids as a characteristic index, Soil Sci., 50, pp.221-232.

[4] 古庄弘明 - 村上道夫 - 中田典秀 - 高田秀重 (2009) : 下 水処理水および道路排水の土壌浸透処理による水質変 化とそのリスク評価，土䁃の物理性，111，pp.17-24.

[5] 地盤工学会 (2008a) : 第3章土の状態を表す諸量を求め る試験 3. 土粒子の密度試験, 土質試験 基本と手引 き, 丸善, pp.19-21.

[6] 地盤工学会 (2008b) : 第4章 土の粒度試験, 土質試験 基本と手引き, 丸善, pp.27-38.

[7] 伊藤豊彰 (1997) : 選択溶解法による可溶鉄・アルミニ 
ウム・ケイ素, B. 酸性シュウ酸塩溶解法, 土䱋環境分 析法編集委員会編, 土壌環境分析法, 博友社, pp.291-294.

[8] 江耀宗・柳田友隆・和田秀徳 - 三谷知世 (2004) : 加熱 土壌のリン吸着特性, 水環境学会誌, 27(2), pp.103-108.

[9] 江耀宗・柳田友隆・三谷知世 (2005a) : カラム実験を用 いた硫酸第一鉄混合 - 加熱処理火山灰土壤による水中 のリン除去，水環境学会誌，28(5), pp.327-332.

[10] 江耀宗・柳田友隆・三谷知世 ・ 野々山弥 (2005b)：リ ン酸イオンを吸着した硫酸第一鉄混合・加熱火山灰土 畩のリン再生及び使用済リン吸着材の再利用, 水環境 学会誌, 28(9), pp.575-580.

[11] 加藤誠軌 - 田口昌司・赤井孝夫 (1998): 蛍光X線分析法, 加藤誠軌 編著, X線発光分析, 内田老鶴圃, p.219.

[12] 川村静夫 (1995)：リン酸, 日本分析化学会北海道支部 編, 水の分析, 化学同人, pp.269-271.

[13］黒田章夫・滝口昇・加藤純一・大竹久夫 (2005)：リン 資源枯渇の危機予測とそれに対応したリン有効利用技 術開発, 環境バイオテクノロジー学会誌，4(2), pp.87-94.

[14] 三谷知世 - 市村綾香 - 下村耕平 - 小池奈緒子 - 大城英 俊・柳田友隆・江輝宗 (2000) : 焼成火山灰土壌による
リン酸イオンの除去, 化学工学論文集, 26(6), pp877-881.

[15] 三谷知世 - 白石協子 - 野々山弥 - 黒江誠子 ・ 柳田友隆 ・ 江耀宗 (2003) : 焼成火山灰土畩を用いた下水二次処理 水からのリン 酸の除去に関する長期的実証実験, 水環 境学会誌, 26(6), pp.393-396.

[16] 南條正巳 (1997a)：リン酸吸収係数，A．リン酸アンモ 二ウム液法, 土畩環境分析法編集委員会編, 土壌環境 分析法, 博友社, pp.262-264.

[17] 南條正巳 (1997b) : 可給態リン酸, B. ブレイ第二法 (準 法), 土壌環境分析法編集委員会編, 土壤環境分析法, 博友社, pp.269-270.

[18] 南條正巳 (1989)：土の化学, 日本化学学会編, 化学総 説, 4, pp.113-127.

[19] 若月利之・小村修一・阿部裕治・泉一成 (1989) : 多段 土壤層法による生活排水中の窒素, リンおよびBOD成 分の除去とその浄化能の評価, 日本土壌肥料化学雑誌, 60(4), pp.335-344.

[20] 柳田友隆・江輝宗 (1994) : 火山灰土䁃のリン酸吸収係 数に及ぼす焼成温度および添加物の影響, 日本土壤肥 料学雑誌, 65(2), pp.171-174.

この論文の公開の質疑または討議は2015年6月30日 まで受付けます。 